\title{
水素結合の特集にあたって
}

\section{千葉大学理学部物理 野田幸男}

\author{
Yukio NODA: The Role of the Special Issue-Hydrogen Bonding
}

The current status of the scientific field of hydrogen bonding is overviewed, and the out line of the special issue is noted.

\section{1. 特集の意義}

物質の結合様式には, 古典電磁気学で理解できるよう なイオン結合やファンデルワールスカから, 量子力学的 な起源で起こる金属結合や共有結合があります.各々に, 程度の差はあれ非常に良く理解されており，原理的には これらの結合形態を議論するのに問題はありません．そ れ以外の結合形態として, 化学の分野では古くから水素 結合の存在が知られていました。「水素結合」はこの自 然界では最もありふれた結合形式で, 生体物質や水など 我々の存在と直接係わっています，ところが，この水素 結合は案外くせもので，その結合原理があまりよく分か っていないし（静電的モデルもありますが私の勉強不足 かもしれない），それ以上に現在に至るまで不可思議な 現象を多く提供しています。

この特集号は, 物理の立場で見た水素結合の不思議か ら出発し, 最後はDNA/RNAにおける水素結合まで概観 しょうという欲張りな企画です．この特集号を読まれた 日本結晶学会会員の皆様は, きっと奇異に思われたこと

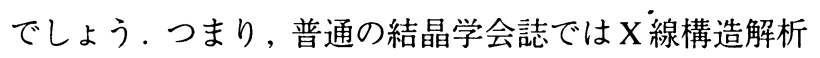
が中心で,こんなに理論の話や液体の話, あるいはNMR, ラマン散乱, 中性子散乱, 計算機実験などを中心とした 記事は今までのスタイルからはずれていると感じること でしょう．じつは，水素結合の問題を物性という立場か ら考えると, どうしてもこのようなスタイルが必要とな ってきます. 結晶学会の存在意義とも深く係わりますが, 「原子レベルでの物質の構造」を多角的に知ろうというの が学会員の要望であるとすると, これを満たすのには結 晶の回折実験のみに執着するのではなく，可能なあらゆ る手段を駆使してゴールに向かうという当然あるべき姿 勢で望む必要があります．この特集号では，かなり意図 的に低分子の構造解析に関連する部分の話を省きました。 これは, その分野が不要という分けでなく, より深く理
解するためには何が必要かに焦点をしほったためで，皆 様がよく知っていることはあえて書かないという態度で す。一方, 生体物質の分野では水素結合の果たす役割が 非常に重要と考えられているのにもかかわらず，まだま だ「構造解析」をどのようにして成功させるかの段階で す. 前半の物理や化学の分野では,できるだけ簡単化し て本質だけを議論し，そのためには特殊な物質を合成し てでも単純化した系で議論して行こうとしているのに対 して, 生体物質の分野では実際に役立っている物質の機 能と構造を何とか結び付けようとしています. 中間的領 域として有機物や水などの両者をつなぐ話題も取り入れ ました。

このように, 各々の分野での話の進展度は色々違いま すが, 目指すものは同じはずで, 物質の示す性質を原子 レベルの構造から深く理解したいということだと思いま す.今回の「水素結合」は, 物理・化学・生物という非 常に広い分野の人が共通の興味の対象として議論できる 結晶学会としてはうってつけの話題ではないでしょうか. この特集号で, 違う分野の人が同じ問題をどのように捉 えているのか, その目指す先にあるのが何かを互いに理 解できれば幸いです。

\section{2. 何が面白いのか}

まず，この特集号では, 水素結合で問題となっている 3 つの事柄の解説を最初に 3 題話的に並べました。つまり, （1）トンネルモデル，(2) 幾何学的効果, (3) アイスル 一ルです，これらは，水素結合型物質の相転移を考える ときに常に重要なキーワードとなります。

歴史的には,アイスルールの重要性がまず指摘されま した。これは, 水や水では, 局所的に見ても $\mathrm{H}_{2} \mathrm{O}$ になっ ているという要請です. 氷の結晶内では一つの酸素回り では $\mathrm{H}_{4} \mathrm{O}$ の四面体構造をとるが，ある瞬間においても $\mathrm{H}_{3} \mathrm{O}, \mathrm{H}_{4} \mathrm{O}, \mathrm{HO}$ になるとエネルギーが高くこのような配 
置をとらないという要請です. KDP と呼ばれる物質でも 状況は同じで, $\mathrm{KH}_{2} \mathrm{PO}_{4}$ という分子式に対応して, 局所 的には $\mathrm{KH}_{2} \mathrm{PO}_{4}$ となることを要請し, 決して $\mathrm{HPO}_{4}$, $\mathrm{H}_{3} \mathrm{PO}_{4}, \mathrm{H}_{4} \mathrm{PO}_{4}$ を低温構造でとらないし摇らぎとしても その様な構造を局所的にとるとエネルギー的に損をする という考えです.アイスルールに関しては, 統計力学的 な観点からはすでに問題は解決されたという印象を受け ますし（松下氏の解説），実際非常に多くの場面で，低 温の構造を理解するための基本原理となっています.

次に重要で不可思議なのが同位元素効果です．水素結 合型誘電体の多くの物質で（もちろんすべての物質では ないが），軽水素 $\mathrm{H}$ を重水素 $\mathrm{D}$ に置換すると相転移温度 が大きく変化することが知られています．これは，強誘 電体, 反強誘電体, 強弾性体, その他さまざまな相転移 で共通にみられる現象です。この相転移温度の違いは, 長 いあいだ $T_{\mathrm{C}}(\mathrm{D}) / T_{\mathrm{C}}(\mathrm{H})$ で議論されておおよそ $\sqrt{2}$ などと いわれていましたが, 最近の孤立水素結合系の研究で $T_{\mathrm{C}}$ $(\mathrm{H})<0 \mathrm{~K}$ の物質が見つかってきてからは $T_{\mathrm{C}}(\mathrm{D})-T_{\mathrm{C}}$ (H) が $100 \mathrm{~K}$ 程度という表現に落ち着いてきたように見 受けられます．この同位元素効果を説明するためのモデ ル（動的側面）として出てきたのがプロトントンネルモ デルです. 量子力学的効果と統計力学の美しさからまた たく間にすべての人が信じてしまいました。ところが, 実 験的にはその証拠が見つからず, 現在, 特に日本では, この単純な考え方に固執するのはまずいということで意 見が一致してきているようです（このあたりの歴史的流 れは,このモデルを出した当事者の徳永氏の解説に詳し く書かれています）．その様な流れの中に出てきたのが 幾何学的効果というモデルです.これは, 理論というよ りは, 構造解析の結果の分類学で, 実験の整理から得ら れた結論です（詳しい解説は本特集号の市川氏の記事を 読んでください）．次にもう少しこのことについて説明 を加えておきます。

一般的に言って, 水素結合の長さは O-D-O の方がO-H○よりも $0.03 \AA$ 程度長いことが知られています。また, 多くの物質での構造解析から, 高温相では, O-H-H-Oや O-D-D-O と水素原子が 2 力所に分裂して見えます. 最近 の構造解析の技術的進歩は驚異的です. 大学 4 年生の卒 業研究でも, 水素結合中の水素や共有結合の電子が見え てあたりまえのことですし（学会誌の表紙は千葉大 4 年 生の作品です），炭素についた水素など見えないほうが おかしい時代です。しかしながら，原理的な問題は常に 残ります，例えば，回折実験では時間・空間平均で見て いることに注意する必要があります。水素が分裂して見 えると述べましたが, 逆に言うと, 見えているものが, 同時に 2 力所に水素が存在しているものか時間的に 2 力 所の案定位置を飛び移っているものか原理的に区別でき ません．さまざまな物質で分類すると 2 力所に見える H-
$\mathrm{H}$ やD-Dの距離にも同じ物質の $\mathrm{H}$ 塩と $\mathrm{D}$ 塩で違いが見え ます. そして重要なことは, 相転移温度 $T_{\mathrm{C}}$ とこれらの構 造的な量 (幾何学的な量) が密接に関係していることが 分かってきました。化学や物理の授業では, $\mathrm{H}$ は原子核に 陽子が1つありDでは陽子と中性子がそれぞれ1つある こと, そして, 外郭電子はともに1つであり, 化学的性 質はまったく同じであると学んだはずです．しかしなが ら，上に述べたように，水素結合のなかではまるで違う 原子のように振舞います。トンネルモデルでは原子核の 質量の差だけで物性を説明しようとしました。だからこ そ，多いに受けたわけです。しかしながら，原子核の質 量差から構造の違いまで説明する必要があります．

この特集号では多くの理論の話が入っています．それ でも紙面の関係から断念した理論的話題があります。一 つは，幾何学的効果を理論的に出そうとした非常に初期 の仕事として Matsushita and Matsubaral)の仕事がありま す.また, 最近の話としては, 水素原子の原子核と電子 および酸素位置の原子を取り込んだ量子力学的な計算が Totsuji and Matsubara奋により行われています。こんなあ たりまえのような計算も実は多体問題でそう簡単には行 えなかったし，そもそも誰も手を付けようとしなかった ことです。この計算では, 水素結合の描像が非常に明確 になります．逆にこの特集号に取り込んだのが最近流行 の第一原理からの計算です. 誘電体の複雑な構造でもこ のような計算が可能となったことに驚きを感じますが， よく勉強するとやはり第一原理と言えどもいくつかの近 似やモデルを使っていることが分かってきます，明快な モデルのもとで大胆に近似した計算がよいのか，なるべ く近似やモデルが表にでない計算がよいのか，それは場 合や立場で使い分ける必要があるのでしょう。これは, 初 期のトンネルモデルの話から連綿と続く問題の様に思え ます. 理論の最後に, Protonic polraronという簡単化した 描像で明快に水素結合の考え方が述べられています（山 田氏の解説）。もうすぐ21 世紀です. 水素結合の問題は, 最初華々しく現われてあっという間に解決したかのよう に見えていたのが，やればやるほど分からなくなり，20 世紀の最後になって，何が積残されているのか，あるい は何が明確になってきたのかがやっと正しく整理されて きたというところです．

後半は，ずっと複雑な系を対象としています．例えば 「水」は簡単な系に見えますが, 水素結合のネットワーク

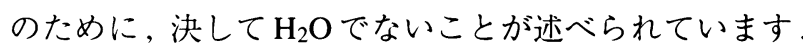
また，有機物質に扔ける水素結合の話も，何となくタン パク質につながりそうな気がします。ビタミンの話は反 応における水素のトンネリングが中心でしたが, 水素結 合の性質が, 生体物質のさまざまな機能に構造面から関 与していることは皆が想像していることです。これに対 するいくつかのアプローチをこの特集号では取り上げて 
いますが，おそらく物理や化学の人にとっては，「まだ まだ」と言う印象を受けるでしょうし，生物の人には 「そんなところまで可能なのか」という印象を受けるでし ょう. 最初に書きましたが, 各々の分野の人の間の交流 がこの特集号で進むことを期待します.

\section{3. さいごに}

今回の企画は,もう 15 年近く続いた「水素結合に関す 万研究班」の活動の成果を, もう少し広い観点と結晶学 という領域から眺め直そうとしたものです。この活動は, 松原武生先生が中心になり始められたもので, 最近では 高工ネルギー加速器機構物質構造研中性子の池田進氏が 別の観点からまとめ役をしておられます。それらの活動 で発表された方々を中心にその他多くの方から推薦をい ただき今回の原稿をお願いしました、重要な分野で抜け ていた方もおられますが, 紙面の関係上これ以上に増や すことは不可能でした。これは取りも直さず, この分野
がいかに活発かという証だと思っています。この企画を 通して, 若い方々が水素結合の面白さに目覚め, 残され た多くの問題を解決してやろうという気概を持つことを 願っています。

\section{文献}

1) E. Matsushita and T. Matsubara: Prog. Theore. Phys. 67, 1 (1982).

2) C. Totsuji and T. Matsubara: J. Phys. Soc. Jpn. 63, 2760 (1994).

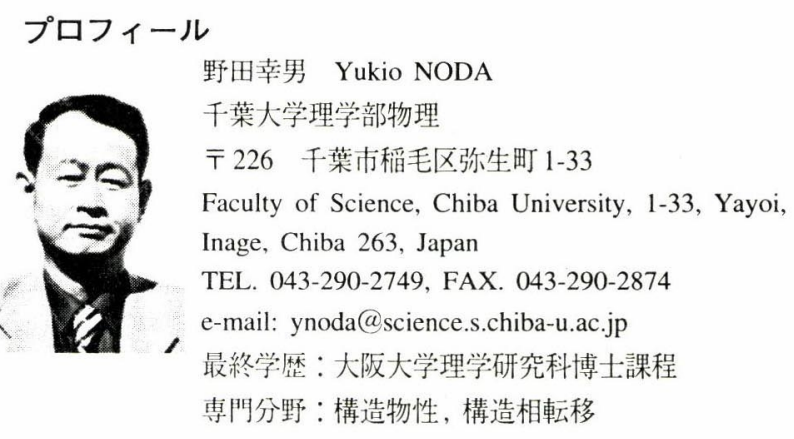

